\title{
RESEARCH ON PRODUCTION OF ENVIRONMENTALLY FRIENDLY ANTAGONISTIC MICROORGANISMS IN THE PREVENTION OF RICE BLIGHT DISEASE FOR AGRICULTURAL PRODUCTION IN VIETNAM
}

\author{
Pham Thi To Oanh \\ Vietnam Cooperative Alliance
}

ABSTRACT

Rice leaf blight disease is one of the common diseases in rice-growing countries, including Vietnam. Research methods were conducted such as assessing the growth of microorganisms, to determine the antagonism of microorganisms, the ability to co-grow, the effectiveness of products, to assess the toxicity of probiotics... The research results showed that the bacterial strains belonging to the actinomycete groups Steptomyces sp., Bacillus spp are capable of antagonizing against Xanthomonas oryzae pv.oryzae (Xoo) causing bacterial leaf blight disease, with 4 strains of bacteria PD17, PD13.1, KND, KXT1 and 2 strains of actinomycetes XKBL2 and XKBL3; Identified suitable conditions for growth: temperature $20^{\circ} \mathrm{C}-50^{\circ} \mathrm{C}, \mathrm{pH} 5.5-8$, fermentation environment to produce probiotics (7-day for fermented powder and 5-day for fermented liquid). The probiotics production process was experimented in laboratory, through practical tests, evaluation of suitability, toxicity test, calculation of economic efficiency and then confirmed to practical effection in Moc Bac Cooperative, Duy Tien district, Ha Nam province.

Keywords: Bacterial leaf blight disease; antagonistic microorganisms; actinomycetes; preparations; rice blight desease

Received: 23/3/2020; Revised: 29/4/2020; Published: 29/4/2020

\section{NGHIÊN CƯU SẢN XUẤT CHẾ PHẨM VI SINH VÂT ĐỐI KHÁNG THÂN THIỆN VỚI MÔI TRƯƠNG TRONG PHÒNG TRU் BẸNH BẠC LÁ LÚA ĐỐI VỚI SẢN XUẤT NÔNG NGHIỆP TẠI VIỆT NAM}

\author{
Phạm Thi Tố Oanh \\ Liên minh Hợp tác xã Việt Nam
}

\section{TÓM TẮT}

Bệnh bạc lá lúa là một trong những bệnh phổ biến ở các nước trồng lúa, trong đó có Việt Nam. Các phương pháp nghiên cứu được sử dụng là đánh giá sự sinh trưởng của vi sinh vật, xác định tính đối kháng của vi sinh vật, khả năng đồng sinh trưởng, hiệu quả của sản phẩm, đánh giá độc tính của chế phẩm,... Kết quả nghiên cứu cho thấy các chủng vi sinh vật thuộc nhóm xạ khuẩn Steptomyces sp., Bacillus spp có khả năng sinh chất đối kháng với vi khuẩn Xanthomonas oryzae pv.oryzae (Xoo) gây bệnh bạc lá lúa, với 4 chủng vi khuẩn PD17, PD13.1, KND, KXT1 và 2 chủng xạ khuẩn XKBL2, XKBL3; xác định được các điều kiện phù hợp cho sinh trưởng: nhiệt độ $20^{\circ} \mathrm{C}-50^{\circ} \mathrm{C}, \mathrm{pH} 5,5-8$, môi trường lên men để sản xuất chế phẩm (dạng bột lên men 7 ngày và dạng lỏng lên men 5 ngày). Quy trình sản xuất chế phẩm được triển khai trong phòng thí nghiệm và trong thực tiễn nhằm đánh giá được tính thích nghi, kiểm tra độc tính, tính toán hiệu quả kinh tế, khẳng định hiệu quả tại hợp tác xã Mộc Bắc, huyện Duy Tiên, tỉnh Hà Nam.

Từ khóa: Bệnh bac lá do vi khuẩn; vi sinh vật đối kháng; xạ khuẩn; chế phẩm; bệnh bạc lá lúa

Ngày nhận bài: 23/3/2020; Ngày hoàn thiện: 29/4/2020; Ngày đăng: 29/4/2020

Email: oanhphamto@gmail.com

DOI: https://doi.org/10.34238/tnu-jst.2020.05.2874 


\section{Introduction}

Bacterial leaf blight disease was first discovered in Fukuoko, Kyushu, Japan in 1884. Currently, rice blight disease has occurred in many countries, especially in Asia (including Vietnam); reducing yield at different levels. In some Asian and Southeast Asian countries, rice blight disease usually reduces yield by $10-20 \%$ but can be as high as $50 \%$ [1]. The main harms are rice leaves, early blighting stems, quickly drying off, ragged rice leaves, adversely affecting the photosynthetic efficiency of dry matter accumulation, reducing the number of ears and seed quantity, reducing grain weight. In Vietnam, rice leaf blight disease is detected in many regions. The disease can arise and develop in all rice crops (winter-spring or summer-autumn), on many different rice varieties. In 2019, Vietnam has 89,272 hectares of rice, of which the area infected with leaf blight disease is 57,234 hectares, an increase compared to previous years [2].

Many studies have focused on the use of chemicals (Japan has allowed the use of chloramphenicol, nickel-dimethyldithiocarbamate, dithianon.... while Vietnam is using Sasa 20WP, 25WP, Kaisin 50, 100WP, Kamsu 2SL, 4SL, Kasumin 2SL...). Research shows that, at present, chemical spraying is not effective when rice fields are seriously infected, large doses of drugs must be used; therefore, there is a huge residue in the environment, inhibiting and destroying many other useful bacteria, leading to ecological imbalance [3].

Selection of disease-resistant rice varieties is a method being implemented. Plant resistance is the ability of the plant to reduce parasite growth and development after the parasite's contact with the host is initiated. Initially, the variety exhibited very good disease resistance but a few years later it became infected again - this is called a break in the resistance of a variety that is caused by the presence of a new bacteria strain with higher toxicity. In
1961, Nishimura studied the disease resistance gene, in which a leaf blight disease resistance was controlled by a dominant gene [4]. The large and long-term scale of rice grown with a single gene may result in the development of pathogens again and the resistance of the single-gene will decrease.

This study focused on the microorganisms belonging to the Steptomyces sp., Bacillus spp actinomycetes groups, which are antagonistic to Xoo causing bacterial leaf blight disease. Research on a trial scale and put into trial production of Xoo antimicrobial products was deployed in the field. The bacterium was first named Bacillus oryzae by Japanese scientists Hori and Bokura in 1911 and is now known as Xanthomonas campestris pv.oryzae. The bacterium has a rod-shaped cell with a round tip, 0.8 to $1 \mu \mathrm{m}$ in length, $0.4-0.7 \mu \mathrm{m}$ in width, surrounded by a mucous membrane; a Gram-negative and non-spore-forming, round, smooth, limeyellow colonies. The bacterium mainly invades the plant through scabbing wounds on leaves through stomata, invading from irrigation water, through the vascular system, and leading to infection of the whole rice plant; can penetrate through the lobe holes at the leaf margins, the tip of the leaf are easily damaged along the veins. The bacteria only survive in water for less than 15 days [5].

\section{Research method}

Research of suitable microorganisms for probiotics production: 6 strains of Xanthomonas oryzae pv.oryzae, 4 strains of Bacillus spp. Trial rice varieties in Moc Bac Cooperative, Duy Tien district, Ha Nam province.

Chemicals: meat extract, yeast extract, amino acid, $\mathrm{NaCl}, \mathrm{K}_{2} \mathrm{HPO}_{4}, \mathrm{KH}_{2} \mathrm{PO}_{4}, \ldots$

Tools: $500 \mathrm{ml}$ conical flask; $250 \mathrm{ml}$, peptri dishes, measuring cups, measuring tubes, alcohol lamps, etc.

Research equipment: microbiological cabinets, sterilizing pots, incubators, voltex machines, microscopes, etc. 
2.1. Methods of assessing the growth of microorganisms:

Methods for determining cell density

$\mathrm{X}=\mathrm{a} \times \mathrm{b} \times 10(\mathrm{CFU} / \mathrm{ml}$ or CFU/g)

a: the number of colonies appearing on the Petri dish

$b$ : reciprocal of dilution concentration

- Quantification of spores: diluted samples were treated with thermal shock at $800 \mathrm{C}$ for 10 minutes, then let it cool in ice water for 5 minutes. Samples were cultured on MPA medium. Count the number of colonies were formed on the medium after 24 hours of incubation at 300C. The number of spores were determined by formula 1 .

- Determination of bacterial biomass (method of measuring optical density OD): The microorganisms cultured in liquid medium after 24 hours are taken to determine the optical density to assess the level of growth among experimental samples. Samples were compared in colors with reference samples (no microbiological culture) by UV-vis colorimeter at $560 \mathrm{~nm}$ [6].

- Determination of dry biomass of actinomycetes formed after culture was collected by filtration through filter paper, dried at $105^{\circ} \mathrm{C}$ to constant mass. Weigh the obtained weight and determine it by formula 2 .

$$
\mathrm{M}_{\mathrm{xkk}}=\mathrm{M}_{1}-\mathrm{M}_{0}
$$
actinomycetes

Of which: $M_{x k k}$ The dry biomass of

$M_{1}:$ Mass of actinomycetes and filter paper after drying

$M_{0}$ : Volume of filter paper

2.2. Methods of determining the antagonism of microorganisms: The method of agar bars, the method of agar wells

2.3. Method for assessing co-growth ability: Studying factors affecting the growth of selected microorganisms: temperature $\left(15^{\circ} \mathrm{C}\right.$, $20^{\circ} \mathrm{C}, 25^{\circ} \mathrm{C}, 30^{\circ} \mathrm{C}, 35^{\circ} \mathrm{C}, 40^{\circ} \mathrm{C}, 45^{\circ} \mathrm{C}$; $\mathrm{pH}(4.0$;
$4.5 ; 5.0 ; 5.5 ; 6.0 ; 7.0 ; 8.0 ; 8.5 ; 9.0 ; 9.5)$ source and concentration of carbon, nitrogen, and mineral.

\subsection{Evaluation of the effectiveness of the product}

Evaluation of the antagonistic ability of probiotics in experiments evaluating the effectiveness of preventing leaf blight disease caused by Xoo bacteria through experiments with different concentrations of probiotics and suspension of Xoo.

Assessing the ability to prevent leaf blight disease in rice: arranging experiments at the jar scale in a laboratory; arranging testing of seed treatment preparations, combined with soil treatment; experimental arrangement of probiotics at Moc Bac Cooperative, Duy Tien district, Ha Nam province.

2.5. Assessment of toxicity of the product: The mice were given oral preparations that differed from their body weight. Track and calculate the number of dead mice in each batch and calculate the $\mathrm{LD}_{50}$ value

The study of semi-chronic toxicity was conducted, monitoring the ability of food intake, movement ability compared to the control group with some hematological indicators, liver and kidney function enzymes [7].

\section{Results and discussion}

Selecting 21 strains of bacteria resistant to Xoo bacteria, Bacillus strains were activated in MPB and MPA environments, tested resistance by agar bars method. The antibacterial ring was measured after 24 hours of incubation at $30^{\circ} \mathrm{C}$. Out of 17 strains that are resistant to bacteria, 9 strains are resistant to all 6 strains of Xoo, 8 strains have selective resistance to some strains of Xoo. Xoo resistance was assessed based on the antibacterial ring of the selected test bacteria meeting the requirements of Xoo strains (ST1-ST6), as shown in Table 1. 
Table 1. Antibacterial rings of selected strains after 24 hours

\begin{tabular}{cccccccc}
\hline \multirow{2}{*}{ No. } & Strain & \multicolumn{5}{c}{ Diameter of resistance ring with single strain Xoo (mm) } \\
\cline { 3 - 7 } & & ST1 & ST2 & ST3 & ST4 & ST5 & ST6 \\
\hline 1 & PD17 & 12 & 15 & 21 & 32 & 22 & 20 \\
2 & KXT1 & 28 & 23 & 15 & 43 & 22 & 13 \\
3 & KND & 24 & 16 & 19 & 33 & 24 & 22 \\
4 & PD13.1 & 32 & 20 & 27 & 35 & 30 & 20 \\
\hline
\end{tabular}

(Source: Center for Science, Technology and Environment, Vietnam Cooperative Alliance, 2019)

Selection of qualified strains, continue culturing after 48 hours, temperature $30^{\circ}$, shake $150 \mathrm{rpm}$; centrifuged fermentation; collect the supernatant fluid and test the resistance to Xoo bacteria by the method of agar wells, shown in the figures.... Based on the size of the antibacterial ring, 4 strains of bacteria PD17, PD13.1, KXT1, KND were selected in figure 1.
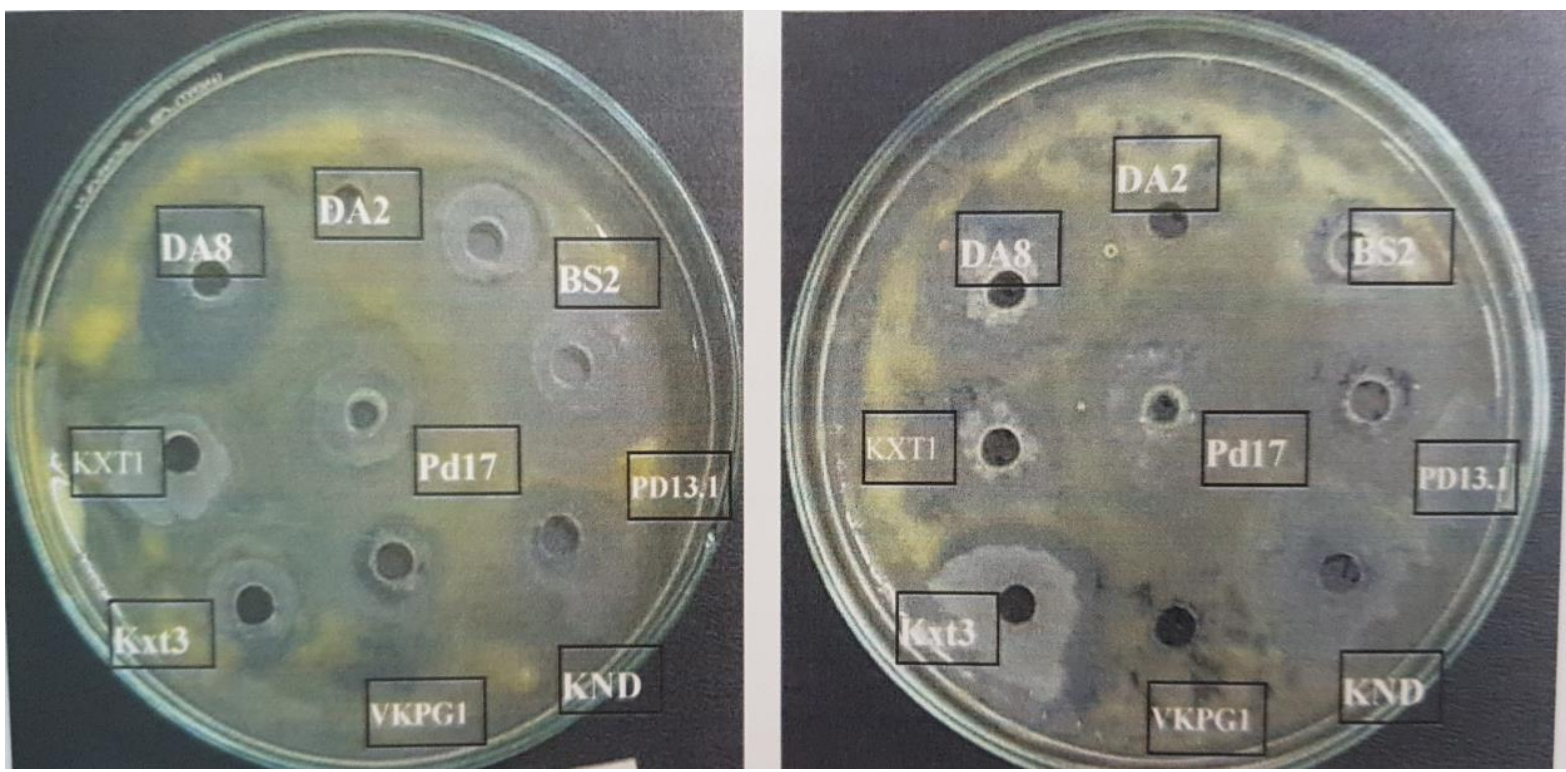

Figure 1. Xoo antibacterial ring of selected bacterial strains (Experiment at the Center for Science, Technology and Environment, Vietnam Cooperative Alliance, 2019)

To select the actinomycetes that are resistant to Xoo, actinomycetes are activated on agar plates containing Gause 2 medium within 5 days, then check the resistance by agar bars method. As a result, only 2 strains XKBL2 and XKBL3 have antagonistic substances against Xoo bacteria and are selected for research on producing Xoo antimicrobial preparations, shown in table 2.

Table 2. Xoo's resistance to bacterial strains

\begin{tabular}{cccccccc}
\hline \multirow{2}{*}{ No. } & Strain & \multicolumn{6}{c}{ Diameter of resistance ring with single strain Xoo (mm) } \\
\cline { 2 - 7 } & & ST1 & ST2 & ST3 & ST4 & ST5 & ST6 \\
\hline 1 & XKBL2 & 12 & 13 & 16 & 10 & 15 & 14 \\
2 & XKBL3 & 15 & 16 & 15 & 11 & 13 & 14 \\
\hline
\end{tabular}

(Source: Center for Science, Technology and Environment, Vietnam Union of Cooperatives, 2019)

Studying factors affecting growth and resistance of selected microorganisms. The appropriate temperature and antimicrobial agent of Xoo are selected at $22-55^{\circ} \mathrm{C}$. Xoo is a gram-negative bacterium with an appropriate growth temperature of $26-30^{\circ} \mathrm{C}$. Two selected strains of actinomycetes belong to the warm-loving group, have the ability to grow and develop in a long temperature range from $15-45^{\circ} \mathrm{C}$. At the temperature of $20-35^{\circ} \mathrm{C}$, the two strains of actinomycetes 
grow and produce the strongest antibacterial substance. Selected strains of microorganisms and actinomycetes are able to adapt to a wide $\mathrm{pH}$ range from 5.0-8.5, thrive at around 6-8, have good salinity tolerance at concentrations from $0.5-5 \%$.

Research the conditions to produce probiotics with mutual antagonism, nutrient source, nitrogen concentration, mineral source..., select appropriate conditions. Fermentation environment for production of Xoo antibacterial preparations containing ingredients: molasses $25 \mathrm{~g} / \mathrm{l}$, soybean meal $25 \mathrm{~g} / \mathrm{l}$, mineral NaCl $3 \mathrm{~g} / \mathrm{l}, \mathrm{KH}_{2} \mathrm{PO}_{4} 1.5 \mathrm{~g} / \mathrm{l}, \mathrm{K}_{2} \mathrm{PHO}_{4} 1.5 \mathrm{~g} / \mathrm{l}$, rice bran $20 \mathrm{~g} / \mathrm{kg}$, soybean meal $25 \mathrm{~g} / \mathrm{kg}$, mineral $\mathrm{KH}_{2} \mathrm{PO}_{4} 1.5 \mathrm{~g} / \mathrm{l}, \mathrm{K}_{2} \mathrm{PHO}_{4} 1.5 \mathrm{~g} / \mathrm{l}, \mathrm{K}_{2} \mathrm{PHO}_{4} 1.5 \mathrm{~g} / \mathrm{kg}$, carrier $1 \mathrm{~kg}$.

Xoo-resistant microorganism preparations are produced in two forms: liquid (5 days) and powder (7 days). Liquid form is used for seed treatment or soil treatment. Powder is used for soil treatment for convenience during use and transportation. The process of producing Xoo-resistant microorganism preparations is shown in Figure 2.

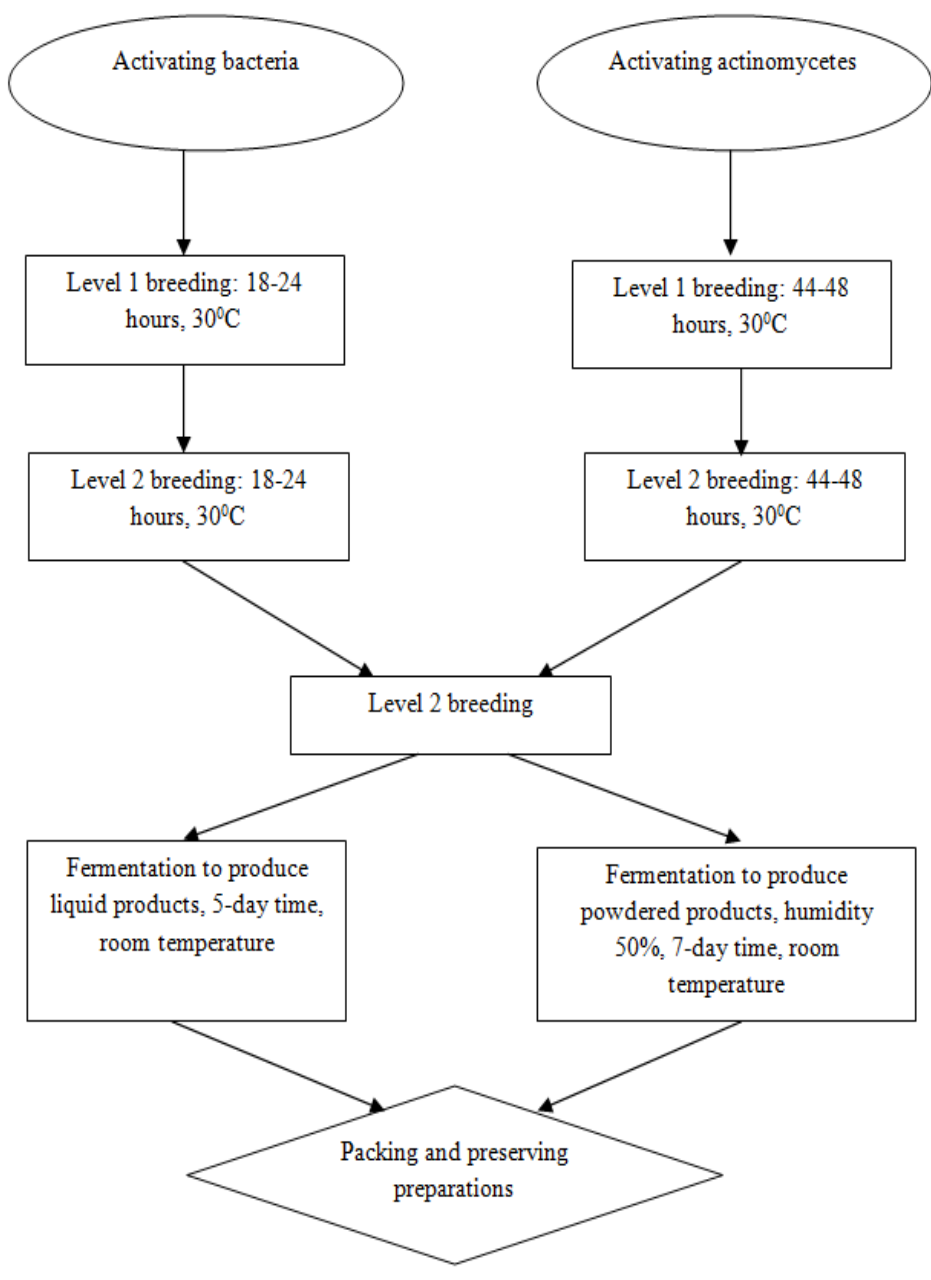

Figure 2. Diagram of production process of Xoo-resistant microorganisms

Before putting the prepartions into actual production, the prepartions were assessed for acute toxicity and semi-chronic toxicity on mice to assess the impact on the ecological and animal environment. Acute toxicity evaluation is based on the number of mice dying within 72 hours for maximum dose and based on external manifestations such as mobility, eating ability, excretion 
ability,... Results show that the product does not exhibit acute toxicity at the studied dose levels, even up to a maximum of $25 \mathrm{~g} / \mathrm{kg}$. Therefore, the $\mathrm{LD}_{50}$ value cannot be determined.

Liquid products are packaged in 1 liter and 5 liter plastic cans. Powdered products are packed in $1 \mathrm{~kg}$ plastic bags. The product is tested for quality through the evaluation that there is no useful microorganism in the product can cause diseases to animals such as E.coli or Salmonella. The quality control results of Xoo-resistant microorganisms are shown in Table 3.

Table 3. Analysis results of the quality of Xoo-resistant microorganisms at agricultural cooperative

\begin{tabular}{clllll}
\hline No. & Analytical criteria & Unit & Methods of analysis & \multicolumn{2}{c}{ Analysis results } \\
\cline { 5 - 6 } & & & & \multicolumn{1}{c}{ C1 } & \multicolumn{1}{c}{ C2 } \\
\hline 1 & Actinomycete & CFU/g & TCVN 4884:2001 & $2.0 \times 10^{8}$ & $1.1 \times 10^{8}$ \\
2 & Bacillus.sp bacteria & CFU/g & TCVN 4884:2001 & $4.7 \times 10^{8}$ & $2.8 \times 10^{8}$ \\
3 & Total Coliform & CFU/g & TCVN 6187-1:2009 & KPHT & KPHT \\
4 & Total E.coli & CFU/g & TCVN 6187-1:2009 & KPHT & KPHT \\
5 & Total Salmonella & CFU/g & TCVN 4884:2001 & KPHT & KPHT \\
\hline
\end{tabular}

(Source: Center for Science, Technology and Environment, Vietnam Cooperative Alliance, 2019)

KPHT: Not detected in sample; M1, M2: Sample preparations

Experimental preparations and economic efficiency calculations in Moc Bac Cooperative, Duy Tien district, Ha Nam province are shown in Table 4.

Table 4. Calculation of economic efficiency of the model (calculated for 1 hectares)

\begin{tabular}{|c|c|c|c|c|c|}
\hline \multirow[t]{2}{*}{ No. } & \multirow[t]{2}{*}{ Production cost } & \multirow[t]{2}{*}{ Quantity } & \multirow[t]{2}{*}{ Unit price } & \multicolumn{2}{|c|}{ Amount (x1,000 VND) } \\
\hline & & & & Experiment & Control \\
\hline I & Production cost & & & 20,360 & 19,067 \\
\hline 1 & Variety $(1.3 \mathrm{~kg} /$ "sao")* & $36 \mathrm{~kg}$ & 31 & 1,116 & 1,116 \\
\hline \multirow[t]{3}{*}{2} & Fertilizer & & & 4,895 & 4,895 \\
\hline & $\begin{array}{l}\text { Nitrogen fertilizer } \\
\mathrm{kg} / \text { /"sao") }\end{array}$ & $55 \mathrm{~kg}$ & 5 & 275 & 275 \\
\hline & $\begin{array}{l}\text { Viet-Japan } \\
\mathrm{kg} / \text { "sao"s }\end{array}$ & $420 \mathrm{~kg}$ & 11 & 4,620 & 4,620 \\
\hline 3 & $\begin{array}{l}\text { Plant protection (drugs, } \\
\text { spraying) }\end{array}$ & & & 5,556 & 5,556 \\
\hline \multirow[t]{3}{*}{4} & Microbiological treatment & & & 1,300 & 0 \\
\hline & Microbial preparations & $200 \mathrm{~kg}$ & 50 & 1,000 & 0 \\
\hline & $\begin{array}{l}\text { Labor cost for spraying } \\
\text { microbial preparations }\end{array}$ & & & 300 & 0 \\
\hline \multirow[t]{4}{*}{5} & Labor cost & & & 7,500 & 7,500 \\
\hline & $\begin{array}{l}\text { Land preparation, grass } \\
\text { removing cost (100,000 } \\
\text { VND/"sao") }\end{array}$ & & & 2,778 & 2,778 \\
\hline & $\begin{array}{l}\text { Preparation of } \\
\text { (soaking rice } \\
\text { sowing seeds) }\end{array}$ & & & 2,778 & 2,778 \\
\hline & $\begin{array}{l}\text { Machine harvesting } \\
(70,000 \mathrm{VND} / \text { "sao") }\end{array}$ & & & 1,994 & 1,994 \\
\hline II & Revenue & 5,560 & 6.5 & 36,140 & 33.02 \\
\hline III & Profit & & & 15,773 & 13,953 \\
\hline IV & $\begin{array}{l}\text { Economic efficiency } \\
\text { (compared to tradition way) }\end{array}$ & & & $11.54 \%$ & \\
\hline
\end{tabular}

(Source: Center for Science, Technology and Environment, Vietnam Cooperative Alliance, 2019) 


\section{Conclusions}

The research has selected strains of microorganisms resistant to Xoo causing leaf blight disease, including 4 strains of bacteria PD17, PD13.1, KND, and KXT1; with a wide growth temperature of $22^{\circ} \mathrm{C}-55^{\circ} \mathrm{C}$, $\mathrm{pH} 5.5-8$; salinity tolerance $0.5-5 \%$. The bacteria and 2 strains of XKBL2 and XKBL3 grow best at $20-35^{\circ} \mathrm{C}$.

The research has also identified nutrition ingredients to serve as the production environment; formulated a process of producing preparations based on the biological properties of selected microorganisms. Preparations are produced in liquid and powder forms. The research has assessed the dynamics of fermentation, thereby determining the necessary fermentation time for production: 7-day for powder, 5-day for liquid form. Bioproducts are tested with results of non-toxic and semichronic toxicity, do not affect the ability of seed germination in practice and have good disease prevention effect when used for seed treatment before sowing and soil treatment before transplanting rice.

When using this bioproduct for soil treatment, the microorganisms have a better ability to adapt to the environment. The density of Bacillus bacteria and actinomycetes is higher than the experimental cells without using the bioproduct. The bioproduct application model helped increase $11.54 \%$ of rice yield in Moc Bac Cooperative, Duy Tien district, Ha Nam province.

\section{REFERENCES}

[1]. K. Gu, J. S. Sangha, Y. Li, and Z. C. Yin, "Highsolutiongenetic mapping of bacterial blightresistance gene Xa-10," Theor. Appl. Genet., vol.116, pp. 155-163, 2008.

[2]. Plant Protection Department, Announcement of pest situation 7 days from 23 to 29 September 2016, Plant Protection Department - Ministry of Agriculture and Rural Development, 2016.

[3]. M. Leila, L. R. M. Rosa, and M. S. M. Ana, "Antagonism of Bacillus spp. Against Xanthomonas campestris pv.campestris," Brazilial archives of Biology and Technology, vol. 48(1), pp. 23-29, 2005.

[4]. A. S. Iyer, and S. R. McCouch, "The rice bacterial blight resistance gen xa -5 encodes a novel form of disease resistance," Mol. Plant Microbe Inter., vol.17, pp. 1348-1354, 2004.

[5]. D. B. Ngo, T. M. T. Le, T. T. H. Trinh, K. T. Pham, M. H. Pham, T. L. Nguyen, T. H. N. Le and V. T. Dang, "35 research and development of biological insecticide Bacillus thuringiensis in Vietnam," 35th Scientific Conference of Vietnam Academy of Science and Technology, 2012, pp. 286-297.

[6]. T. P. H. Pham, V. H. Duong, T. V. Nguyen, H. A. Nguyen, T. A. D. Nguyen, T. K. Q. Nguyen, H. M. Q. Nguyen, and V. T. Nguyen, "Research on stimulating antibacterial actinomycetes to kill Xanthomonas oryzae pv.oryzae causing rice leaf blight disease in Vietnam," The 4th National Scientific Conference on Ecology and Microbiological Resources, 2015, pp. 1127-1133.

[7]. T. C. Tang, T. M. A. Dang, T. H. Nguyen and V. T. Tran, "Application of Sagi-Bio products to handle solid waste for pig raising," Scientific report - National biological conference 2013 Episode 2, 2013, pp. 80-84. 